\title{
Cysts and their formation in some neustonic Euglena species
}

\author{
F. Hindák ${ }^{1}$ \\ K. Wołowski ${ }^{2}$ \\ A. Hindáková 1
}

Keywords : Euglena agilis, E. anabaena, E. viridis, Euglena-neuston, resting cysts, SEM envelope structure, Slovakia.

Morphology, ultrastructure and formation of resting cysts of $E$. agilis H.J. Carter and $E$. anabaena Mainx are described. The SEM micrographs of cysts of $E$. anabaena and $E$. agilis are presented for the first time. Information on the neuston film formed by these species is given. An ecological database and list of accompanying species is also included.

Les kystes chez quelques espèces neustoniques du genre Euglena

Mots-clés : Euglena agilis, E. anabaena, E. viridis, Euglena-neuston, kystes,structure, MEB, Slovaquie.

La morphologie, l'ultrastructure et la formation des kystes chez Euglena agilis H.J. Carter et $E$. anabaena Mainx sont décrits. Des photographies de ces deux espèces, réalisées au microscope électronique à balayage (MEB); sont présentées pour la première fois. Des informations sur le film neustonique constitué par ces deux espèces sont données. Des précisions sur leur écologie ainsi que la liste des espèces accompagnatrices sont également fournies.

\section{Introduction}

Many representatives of the genus Euglena Ehrenb. are able to transform their bodies from characteristic unicellular motile stages into non-motile mucilaginous colonies. Euglenoid monads during the encystation change their original shape into ovoid, oval up to spherical forms, losing flagella. Subpellicular mucus bodies eject mucilage (which consists of polysaccharide and /or glycoproteins) that forms layers around the Euglena cell (Cogburn \& Schiff 1984). Mucilaginous envelopes (cysts) are usually conspicuous, spherical, flask-shaped (E. tuba H.J. Carter), or pentagonal ( $D i-$ stigma Ehrenb.). In the phycological literature (e.g. Skuja 1948, Gojdics 1953, Huber-Pestalozzi 1955, Starmach 1983) these mucilaginous colonies are usual-

\footnotetext{
1. Institute of Botany, Slovak Academy of Sciences, Dúbravská cesta 14, SK-84223 Bratislava - Slovakia.

E-mail : botuhind@savba.savba.sk

2. Institute of Botany, Polish Academy of Sciences, ul. Lubicz 46, PL-31-512 Kraków - Poland.

E-mail : wolowski@ib-pan.krakow.pl
}

ly called palmelloid or gloeocystis stages. Three basic types of cyst are formed by Euglena species : (i) protective - generally have a heavy, sometimes stratified, wall and containing one cell ; (ii) reproductive (palmella formation) - have a thin, elastic, permeable membrane that increases in diameter as the cells divide, palmella formation occurs among large number of cells (Gojdics 1953), the cells are nonflagellated ; (iii) temporary, resting, or transitory cysts - have a wall that is impervious to water, but which contains a small pore.

Some species of Euglena may form more than one of the cysts during the life cycle (Buetow 1968). According to Jahn 1951 (after Buetow 1968), E. gracilis G.A. Klebs can form a reproductive cyst or a temporary cyst. The cells embedded in mucilaginous colonies are able to divide and move slightly in their own mucilage capsule changing position of the cell; and also reform the flagella and leave the mucilage. Palmella stage occurs among large numbers of cells (Gojdics 1953). Such colonies are free-floating in the plankton or fall into the metaphyton/benthos. In $E$. gracilis and $E$. viridis Ehrenb. the cyst may contain 32-64 cells (Jahn, after Buetow 1968)). 
Several Euglena species create a neuston film - a red neustonic film is caused by $E$. sanguinea Ehrenb., a green one by $E$. polymorpha P.A. Dang., E. granulata (G.A. Klebs) Schmitz, E. agilis H.J. Carter, E. viridis, E. anabaena Mainx - (see cited monographs). A unique neustonic bloom of $E$. granulata var. polymorpha (P.A. Dang.) T.G. Popova (=E. polymorpha) was observed in an experimental fishpond at Laskowa near Zator, S Poland, by Bednarz (1974). On the surface of the water a pectin-like hyaline net was formed, in the mesh of which moved Euglena cells with flagella always directed downwards the water (Figs. 1-4).

Another type of resting cysts has been observed in Euglena agilis $(=$ E. pisciformis G.A. Klebs) by the first author of this article (Hindák 1982, 1986). Motile cells of Euglena entered a colonial mucilage of planktic species of the genus Microcystis [M. aeruginosa (Kütz.) Kütz., M. minutissima W. West] and Anabaenopsis elenkinii Miller, rarely also of other cyanophytes, changing into oval up to spherical bodies and producing a brownish to dark brown envelope layer around. Because of some similarities in the shape and colour of these envelopes with loricae of the genus Trachelomonas Ehrenb., the endogloeic cysts were called Trachelomonas-like resting cysts (Figs. 5, 6). These cysts did not exhibit any conspicuous tendency to wait out the unfavourable life conditions, as is characteristic of other types of resting stages, since the protoplast of cysts divided after a definite, sometimes relatively short time, and the daughter protoplasts were able to emerge from the Trachelomonas-like brown loricae by an intensive changing cell motion and, sometimes, also with the help of a long flagellum, and move. The new daughter protoplasts then remain either in the same host colony, or leave it, moving freely in the water and/or passing into the mucilage of another host colony. The wall of Trachelomonas-like cysts was irregularly granulated, but no regular structure and no opening for the flagellum was observed as in the genus Trachelomonas (Fig. 5). In contrast to the mentioned palmelloid stages in Euglena, these cysts occurred in cyanophyte colonies mostly solitary or, in small groups, never forming large colonies.

In recent years, similar cysts with a brown Trachelomonas-like envelope were found in neuston films formed by $E$. agilis, E. anabaena and $E$. viridis. However, in $E$. agilis these neustonic cysts (Figs. 7-9, 23-27) differed from those found in planktonic cyanophyte colonies (Figs. 5, 6), both, in the envelope structure and the ecology. In this article the formation of resting cysts of the mentioned two species and morphology of cysts under the light and electron microscopy are described and discussed.

\section{Study area, material and methods}

Euglena neuston bloom was studied from two places, both located within the city limits of Bratislava. One locality is a small forest fishpond in Zelezná Studienka, situated ca $2 \mathrm{~km}$ northwest of the State sanatorium, while the other one a big garden flower-pot with accumulated rainwater placed in the park of the Slovak National Uprising Square.

The investigated forest fishpond is about $0.5 \mathrm{~km}^{2}$, and has a slightly prolongated rectangular shape, max. depth about $2 \mathrm{~m}, \mathrm{pH} 7.6-7.8$, temperature $18-21^{\circ} \mathrm{C}$ (in the second half of July 1994). The macroscopic neuston bloom was observed only in July and August 1994. The fishpond was discharged in the previous autumn and in the late spring and summer 1994 refilled but only to half the usual water level. Because of favourable conditions, i.e. a relatively hot summer that year, low water level - and thus partly protected strong wind the neuston film developed enormously on the surface of the fishpond, at first sight resembling a cyanophyte water bloom (Fig. 22). The neuston bloom covered the water surface in the form of a fine film, but when the neuston was blown toward the shore it became up to several $\mathrm{mm}$ thick and deep green in colour. The neuston film took about a third of the water surface of the fishpond, with the maximum near the shore and outlet. Under unfavourable conditions, e.g. by strong wind or heavy rain, the neuston film was mixed with the plankton water and Euglena-cells left the mucilage capsules, transformed into motile stages with flagella and swam in the water. However, under favourable conditions the neuston film formed again. During neustonic bloom also the water of the fishpond itself was green because of the dominance of motile cells of Euglena anabaena and $E$. agilis in the planktonic community. The neuston bloom disappeared in autumn and since then has never again been formed in this locality.

The second place where an euglenoid neuston was observed is from ecological point of view quite different from the previous one. In a small park in the Slovak National Uprising Square, in a garden flower-pot about $50 \times 50 \times 70 \mathrm{~cm}$ in size (at the time the pot was without flowers but still contained garden soil), rainwater had accumulated. On the surface of the pot water layer a conspicuous green neuston film developed at the end of September 1995.

For LM observations a Diaplan Leica microscope was used, and for SEM studies the REM JEOL JSM- 
(3)
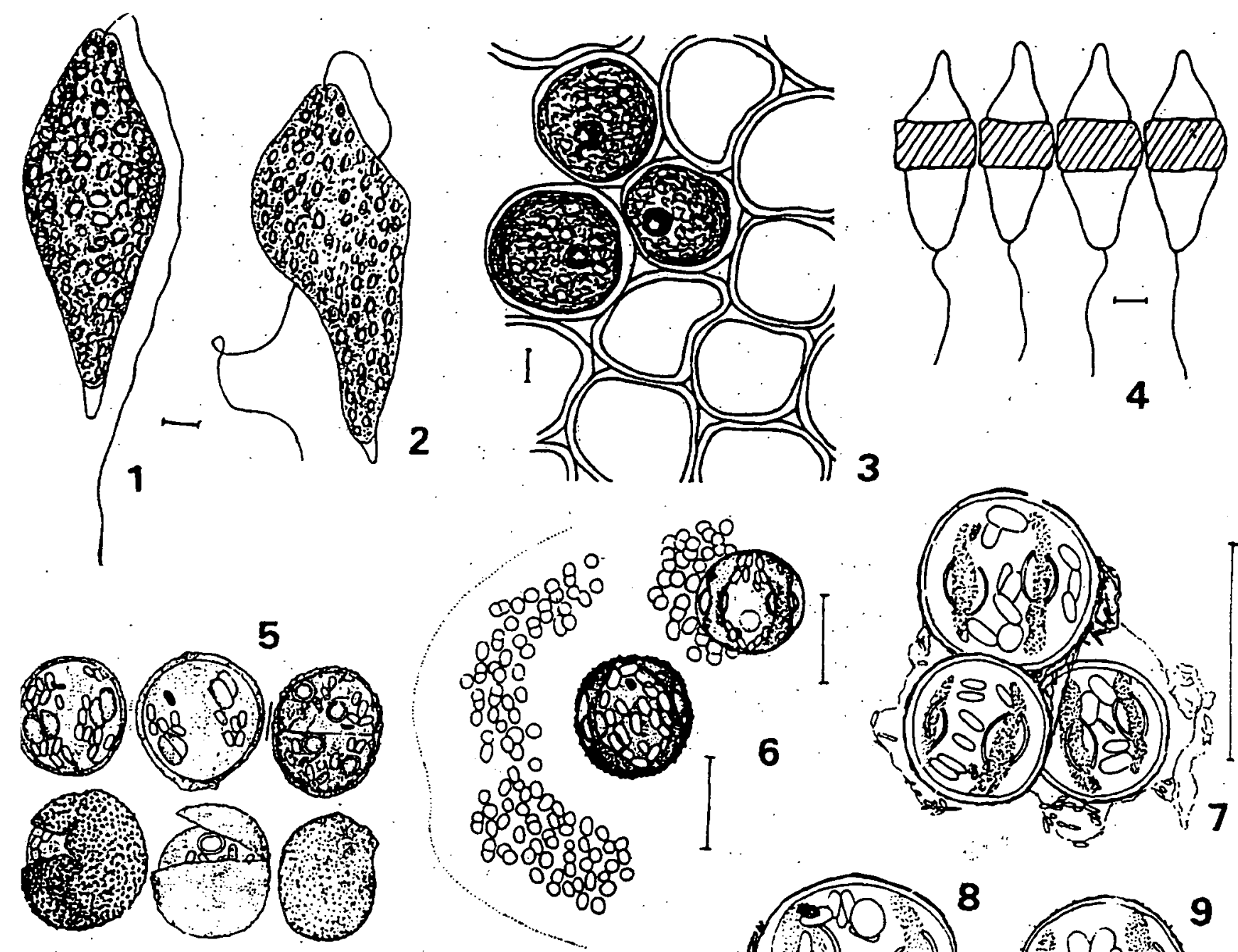

\section{3}
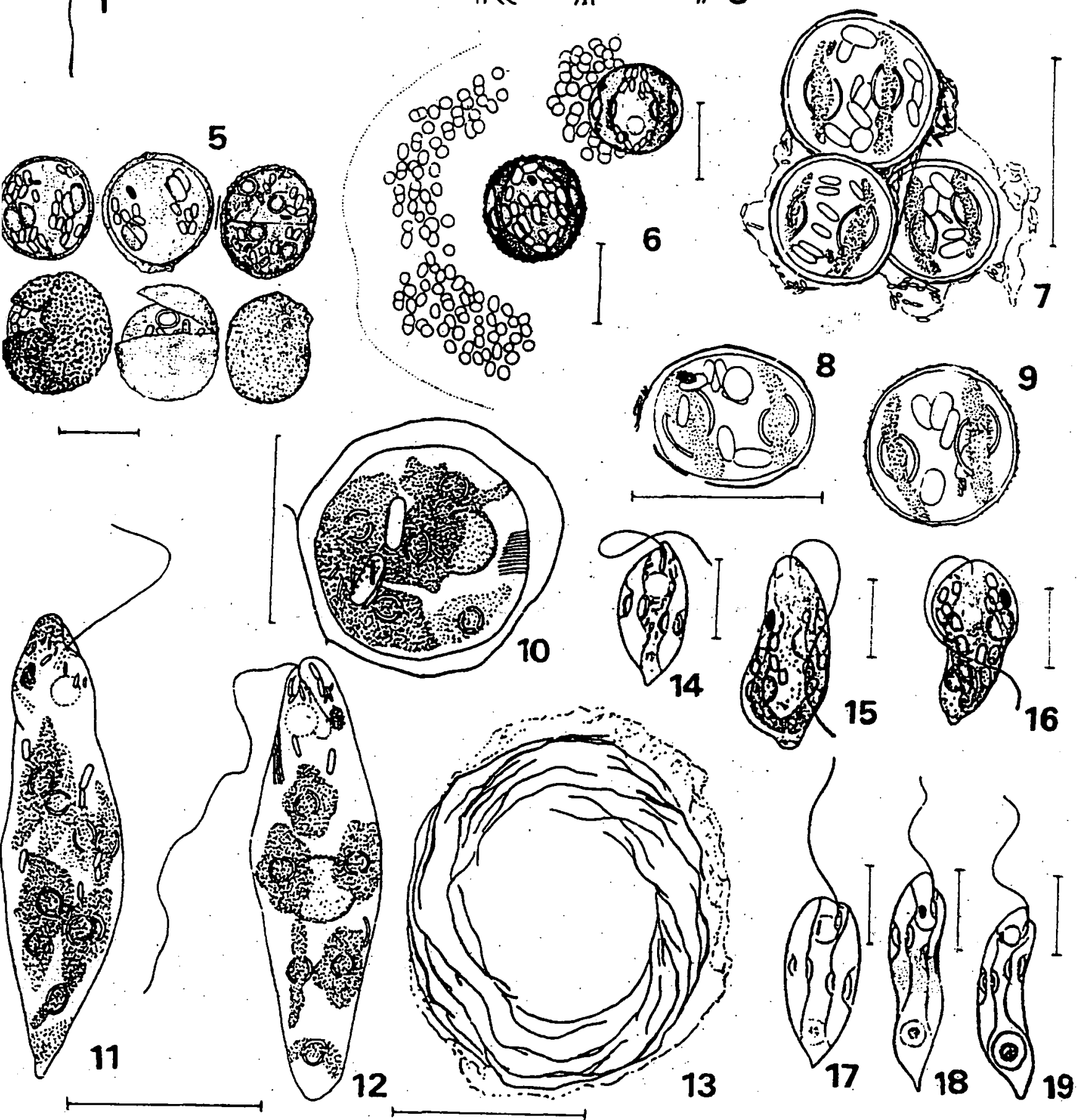

Figs. 1-19. 1, $2:$ Euglena granulata var. polymorpha, free swimming cells ; $3:$ network with empty meshes and those with cells ; $4:$ scheme of distribution of the Euglena cells in the network (from Bednarz 1974);5-9, 14-19: cysts of E. agilis : 5, 6: protective cysts living in the mucilage of Microcystis minutissima (from Hindák 1982, 1986) ; 7-9 : resting cysts ; $14-19$ :free swimming cells (after Hindák 1986) ; 10-13 : E. anabaena : 10,13 : protective cysts, $11,12:$ free swimming cells. Scales $=10 \mu \mathrm{m}$.

Figs. 1-19. 1, 2 : Euglena granulata var. polymorpha, cellules libres ; 3 : vue du réseau visible à la surface de l'eau avec kystes encore présents et enveloppes vides (d'après Bednarz 1974) ; 4 : schéma de la distribution des cellules d'Euglena dans le réseau (d'après Bednarz 1974) ; 5-9, 14-19: kystes de Euglena agilis : 5, 6 : kystes vivants à l'intérieur du mucilage de Microcystis minutissima (d'après Hindák 1982, 1986) ; 7-9: kystes en phase de repos ; 14-19: cellules libres (d'après Hindák 1986) ; 10-13:E. anabaena : 10, $13:$ kystes, $11,12:$ cellules libres. Echelles $=10 \mu \mathrm{m}$. 
6300. Material from the fishpond was fixed with glutaraldehyde, dehydrated with acetone or alcohol series, critical point dried and sputtered with gold.

\section{Results and discussion}

\subsection{Neuston of the forest fishpond in Bratislava- Železná Studienka}

\subsubsection{Dominant species of the neuston film}

As already mentioned, the neuston film of the forest fishpond consisted predominantly of resting cysts of Euglena anabaena (Figs 11, 12, 20, 21, 28) and E. agilis (Figs 14-19, 38). Under favourable climatic conditions, the motile cells of both species, abundantly occurring in the plankton of the fishpond that summer, moved upward to the water surface, attached to the water film, and transformed into resting cysts. From the beginning of the neuston development, the film resembled a hyaline honeycomb or a network, i.e. the motile cells were fixed to the water film and joined by the mucilage very tightly, so that the neighbouring cells created a one-layered compact or perforated film (Figs. 7, $13,22)$. The motile cells were fixed to the surface water film by their antapical part, having their apical part with the flagellum being submerged in the water (Figs. $23,24,27)$. The attached cells gradually produced irregular mucilage layers, and created a special envelope directly round their bodies. The envelopes were at the beginning hyaline and thin, but later on thicker and brownish.

The neustonic network was mainly formed by the cysts of $E$. anabaena (Figs. 10,13, 28-31) in which vegetative cells were conspicuously larger than those of E. agilis (Figs. 38-41). The cysts of the latter species usually filled empty gaps between those of the former one. Owing to strong wind and other forms of mechanical movement of the water surface (and also during the transportation of the samples of the neuston film into the laboratory), the Euglena cells in the neuston were able to move from it very quickly, leave the film layer, and swim again in free water by means of flagella (Figs. 11, 12, 14-19, 20, 21, 28, 38).

\section{- Morphology of cysts of Euglena anabaena}

The cysts of E. anabaena (Fig. 31) were from the top view, circular to irregularly circular or broadly oval, from the side view, oval and slightly flattened (Figs. 29, 30). Developed cysts were completely covered by an envelope (Figs. 38-41). The surface of envelopes was without any regular structures, mostly smooth or finely rough and porous. Some envelopes were allusively concentrically layered or spirally twisted (as a fine replica of a spiral construction of Euglena cells), only rarely with a central porus in the top (Figs. 36, 37). The envelope was composed of fine fibrils (Fig. 35). The upper part of the envelopes (obviously being in contact with the open air) was thicker than the submerged lower part, thus forming a cap as is known in other neustonic microorganisms (Pascher 1942, Korshikov 1953).

\section{- Morphology of cysts of Euglena agilis}

Morphology of cysts of Euglena agilis (Figs. 38, 39) exhibited many features of those of $E$. anabaena, namely in origin, structure and composition. However, there were some differences (see Hindák 1982, 1986). The cysts were protective with a heavy, sometimes stratified wall (Figs. 40, 41).

\subsubsection{Accompanying species of the neuston film}

Apart from strongly dominant species of Euglena anabaena and E. agilis, other cyanophyte and algal species were found as a part or an admixture of the neuston film. This is only to enumerate accompanying species, because they will be treated in detail elsewhere. From Cyanophyta it was mainly Trichormus sp., while other species, such as Merismopedia tenuissima, Lyngbya sp. occurred only sporadically. From other groups of algae were present Heterothrix ulotrichoides $\mathrm{Pa}$ scher (Xanthophyceae), Amphora libyca Ehrenb., Nitzschia palea (Kütz.) W. Sm., Navicula cryptotenella Lange-Bert., N. pupula Kütz. (Bacillariophyceae), but mainly green flagellates [Chlamydomonas petasus H. Ettl, C. mantonii (H. Ettl) H. Ettl, C. epibiotica $\mathrm{H}$. Ettl, C. spinifera $\mathrm{H}$. Ettl, Carteria asterochloris $\mathrm{H}$. Ettl, Diplostauron angulosum Korshikov, Pedinomonas minor Korshikov] and chlorococcal algae (Nautococcus mammilatus Korshikov, Ferricystis mucicola Hindák). Taxa published from the territory of Slovakia for the first time are marked with asterisk $(*)$ (Hindák \& Hindáková 1998).

List of taxa found in the neuston film :

\section{Cyanophyta}

Lyngbya sp., Merismopedia tenuissima Lemmerm., Trichormus sp.

\section{Xanthophyceae \\ *Heterothrix ulotrichoides Pascher}

\section{Bacillariophyceae}

Amphora libyca Ehrenb., Navicula cryptotenella Lange-Bert., N. pupula Kütz., Nitzschia palea (Kütz.) W. Sm. 

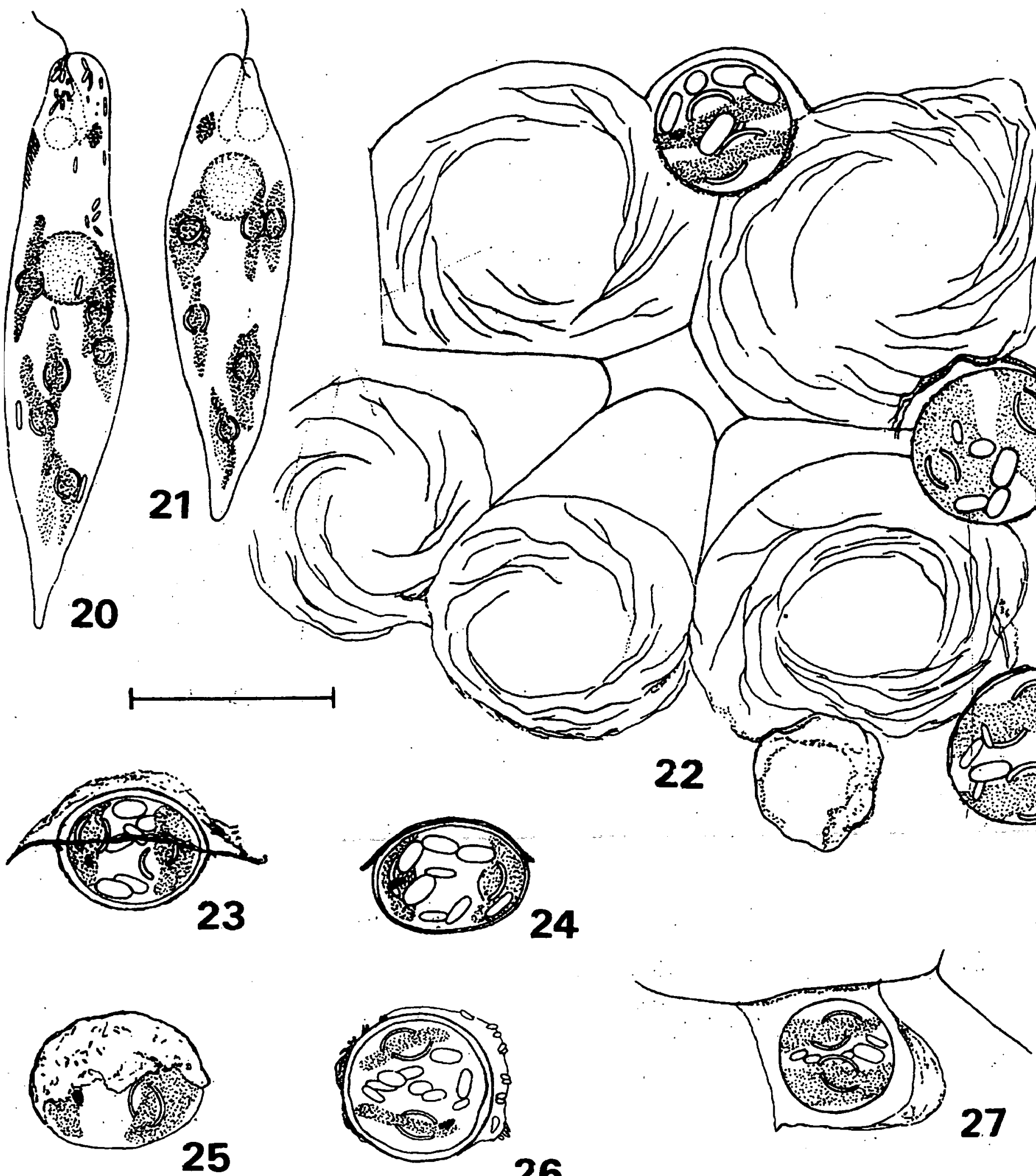

26

Figs. 20-27. 20, 21 : Euglena anabaena ; 22 : neustonic network with cysts of $E$. anabaena and $E$. agilis ; 23-27: cysts of $E$. agilis. Scales $=10 \mu \mathrm{m}$.

Figs. 20-27. 20, 21 : Euglena anabaena ; 22 : film neustonique avec kystes de E. anabaena et E. agilis ; 23-27 : kystes de E. agilis. Echelles $=10 \mu \mathrm{m}$. 

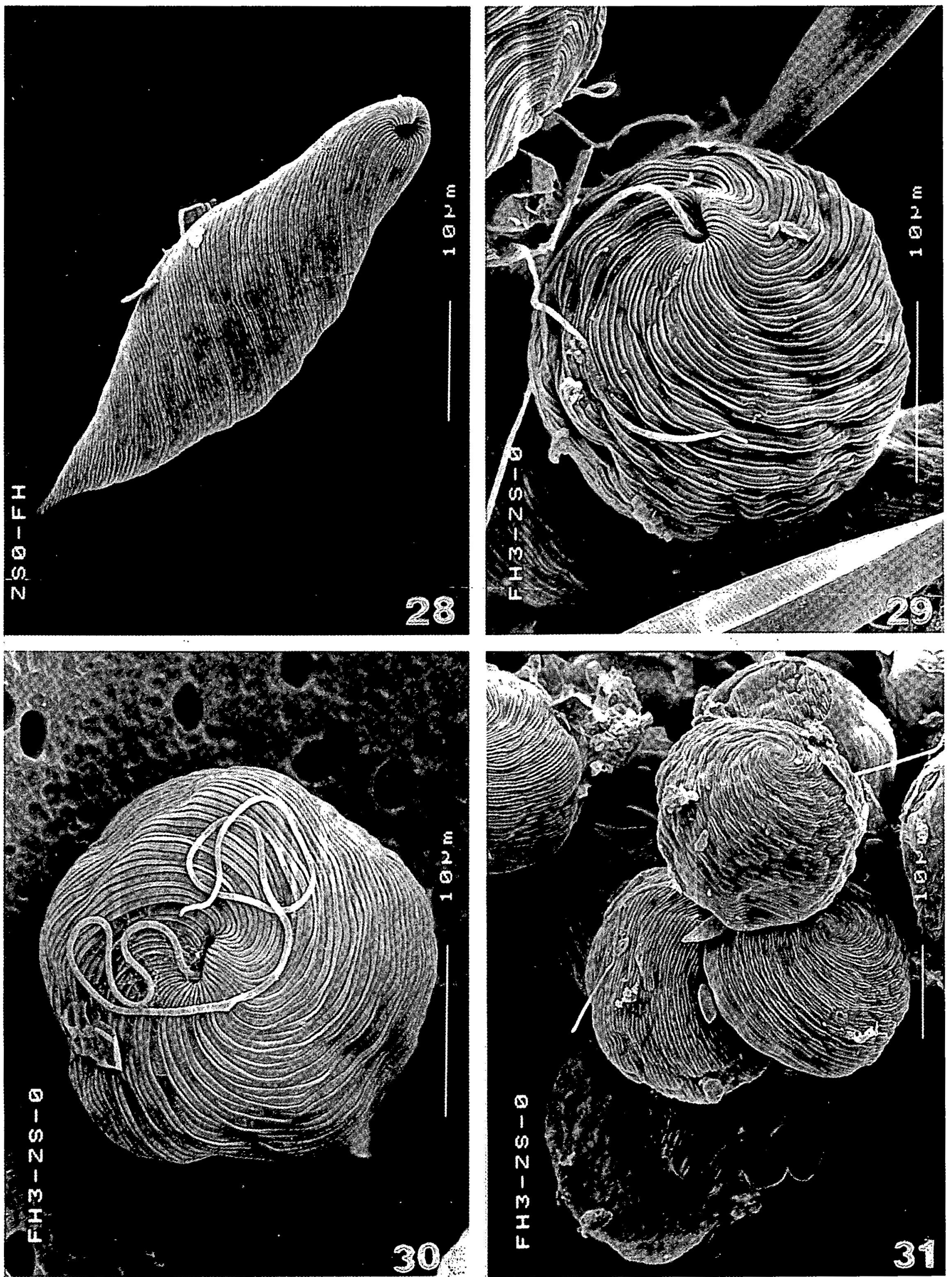

Figs. 28-31. $28:$ Euglena anabaena, free swimming cell $; 29,30:$ cysts with clearly visible flagellum ; $31:$ group of resting cysts. SEM. Scales $=10 \mu \mathrm{m}$.

Figs. 28-31. 28 MEB : Euglena anabaena, cellules libres ; 29, $30:$ kystes avec flagelle bien visible ; 31 : groupe de kystes. Echelles : $10 \mu \mathrm{m}$. 



Figs. 32-35. Euglena anabaena : $32-34:$ resting cysts ; $35:$ fragment of protective cyst. SEM. Scales $=1 \mu \mathrm{m}$.

Figs. 32-35. MEB : Euglena anabaena : 32-34 : kystes ; $35:$ fragment de kyste. Echelles $=1 \mu \mathrm{m}$. 

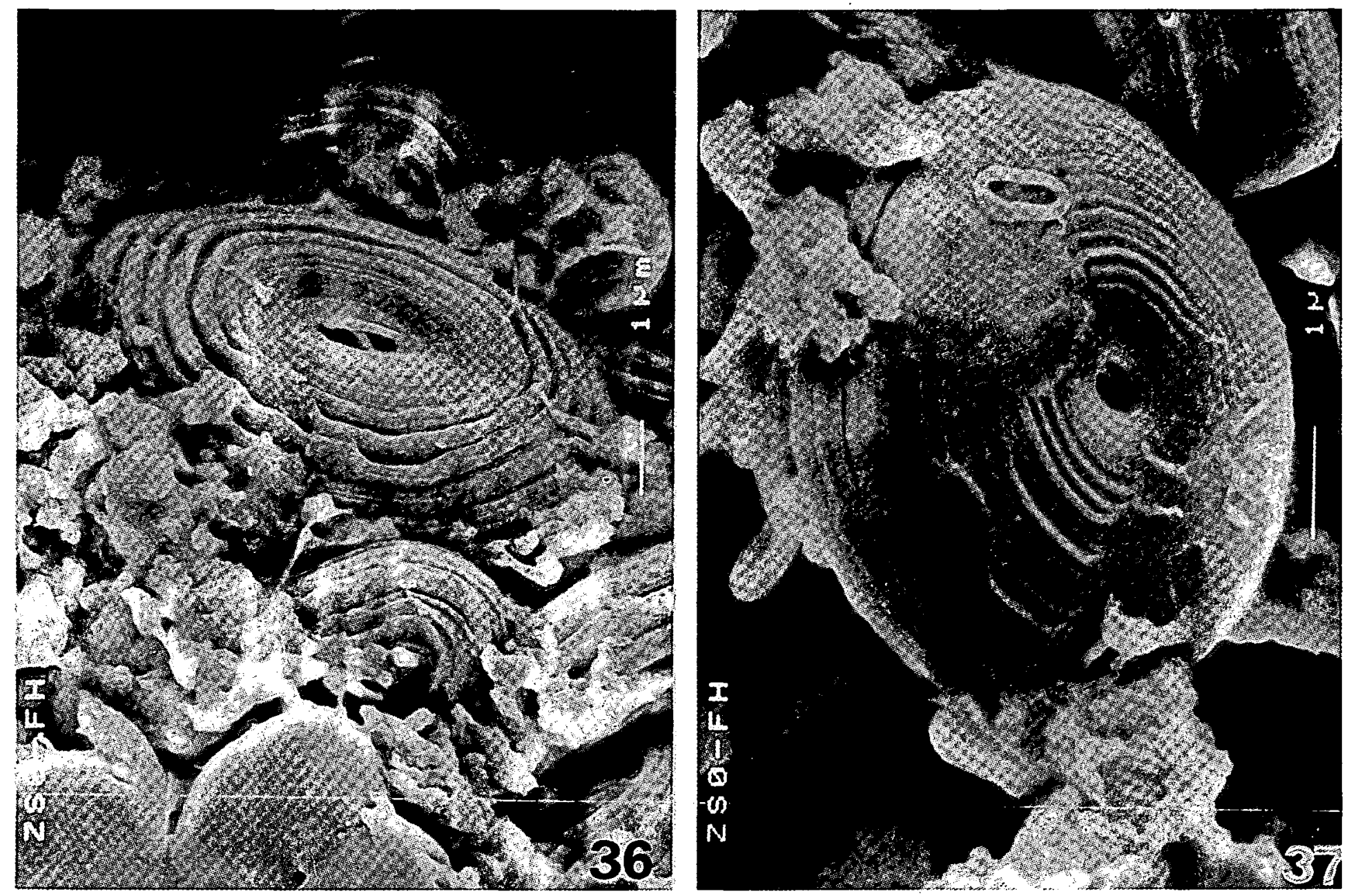

Figs. 36-37. Envelope as fine replica of spirally striated Euglena cells. SEM. Scales $=1 \mu \mathrm{m}$.

Figs. 36-37. MEB : Enveloppes de kystes apparaissant comme un replicat de stries hélicoïdales de la cuticule des cellules de Euglena. Echelles $=1 \mu \mathrm{m}$.

\section{Chlorophyceae}

Volvocales : Carteria asterochloris H. Ettl, Chlamydomonas epibiotica $\mathrm{H}$. Ettl, ${ }^{*}$ C. mantonii $(\mathrm{H}$. Ettl) $\mathrm{H}$. Ettl, ${ }^{*} C$. petasus H. Ettl, C. spinifera H. Ettl, Diplostauron angulosum Korshikov, Pedinomonas minor Korshikov

Chlorococcales : Ferricystis mucicola Hindák, *Nautococcus mammilatus Korshikov

\section{Euglenophyceae}

Euglena anabaena Mainx, E. agilis H.J. Carter

\subsection{Phytoplankton species composition of the forest fishpond during the neustonic bloom}

The plankton of the forest fishpond was dominated by two species of the genus Euglena : E. agilis and $E$. anabaena which also dominated in the neuston film. Other cyanophytes and groups of algae (except diatoms) occurred relatively in small number of species and quantity.
List of taxa found in the plankton :

\section{Cyanophyta}

Merismopedia tenuissima Lemmerm., Microcystis wesenbergii (Komárek) Komárek, Snowella lacustris (Chodat) Komárek et Hindák

\section{Chrysophyceae}

Dinobryon divergens O.E. Imhof

\section{Bacillariophyceae}

Aulacoseira granulata (Ehrenb.) Simonsen, Cyclostephanos dubius (Fricke) Round, Cyclotella atomus Hust., C. meneghiniana Kütz., C. pseudostelligera Hust., C. quadrijuncta (Schröt.) Keissl., C. stelligera Cleve et Grunow, Stephanodiscus binderanus (Kütz.) Willi Krieg., S. hantzschii Grunow, Thallasiosira pseudonana Hasle et Heimdal, Achnanthes lanceolata (Bréb. ex Kütz.) Grunow, A.minutisssima Kütz., A. subatomoides (Hust.) Lange-Bert., Amphora lybica Ehrenb., A. montana Krasske, A. pediculus (Kütz.) Grunow, Asterionella formosa Hassal, Caloneis bacillum (Grunow) Cleve, $C$. silicula (Ehrenb.) Cleve, $C y$ - 

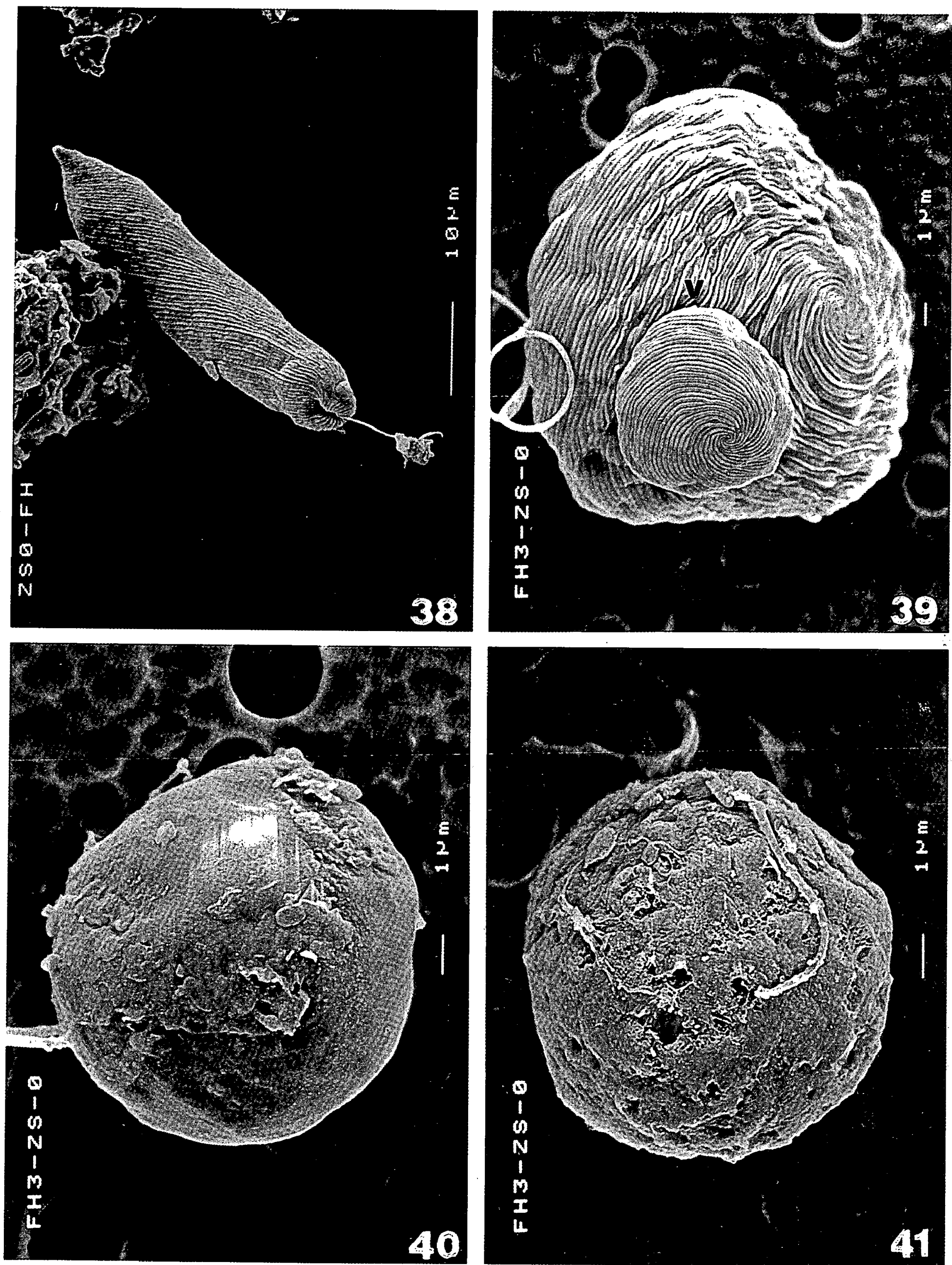

Figs. 38-41. Euglena agilis : 38 : free swimming cell ; 39 : palmella stage of $E$. agilis (small cell arrow) and large one of $E$. anabaena ; 40,41 : protective cysts. SEM. Scales $=10 \mu \mathrm{m}(38), 1 \mu \mathrm{m}(39-41)$.

Figs. 38-41. MEB : Euglena agilis : 38 : cellule libre ; 39 : stade palmella de $E$. agilis (la petite cellule, flèche) et de $E$. anabaena ; 40,41 : kystes. Echelles $=10 \mu \mathrm{m}(38), 1 \mu \mathrm{m}(39-41)$. 
matopleura solea (Bréb.) W. Sm., Cymbella cistula (Ehrenb.) Kirchn., C. microcephala Grunow, C. minuta Hilse, C. sinuata W. Greg., Diploneis oculata (Bréb.) Cleve, Fragilaria crotonensis Kitton, F. parasitica var. subconstricta Grunow, $F$. ulna var. ulna (Nitzsch) Lange-Bert., $F$. ulna var. acus (Kütz.) Lange-Bert., Frustulia vulgaris (Thwaites) de Toni, Gomphonema augur var. turris (Ehrenb.) Lange-Bert., $G$. parvulum (Kütz.) Kütz., G. sarcophagus W. Greg., G. truncatum Ehrenb., Gyrosigma acuminatum (Kütz.) Rabenh., G. attenuatum (Kütz.) Rabenh., Meridion circulare (Grev.) C. Agardh, Navicula accomoda Hust., N. capitata Ehrenb., N. capitatoradiata H. Germ., $N$. cryptotenella Lange-Bert., $N$. elginensis (W. Greg.) Ralfs, $N$. gregaria Donkin, $N$. libonensis Schoeman, ${ }^{*} N$. medioconvexa Hust., $N$. menisculus Schum., N. phyllepta Kütz., N. pupula Kütz., N. pygmaea Kütz., N. subminuscula Manguin, $N$. tripunctata (O.F. Müll.) Bory, N. trivialis Lange-Bert., N. veneta Kütz., Neidium ampliatum (Ehrenb.) Krammer, Nitzschia acicularis (Kütz.) W. Sm., N. acidoclinata Lange-Bert., $N$. amphibia Grunow, $N$. capitellata Hust., $N$. fonticola Grunow, $N$. hungarica Grunow, $N$. inconspicua Grunow, $N$. intermedia Hantzsch, $N$. levidensis (W. Sm.) Grunow, N. palea (Kütz.) W. Sm., $N$. pusilla Grunow, $N$. recta Hantzsch, $N$. sigmoidea (Nitzsch) W. Sm., N. subacicularis (Kütz.) Hantzsch, *N. supralitorea Lange-Bert., $N$. tubicola Grunow, Pinnularia gibba Ehrenb., P. neomajor Krammer, $P$. obscura Krasske, P. subcapitata W. Greg., P. viridis (Nitzsch) Ehrenb., Rhoicosphenia abbreviata (C. Agardh) Lange-Bert., Stauroneis legumen (Ehrenb.) Kütz., Surirella brebissonii var. brebissonii Krammer et Lange-Bert., S. brebissonii var. kuetzingii Krammer et Lange-Bert., $S$. gracilis Grunow, S. linearis W. Sm., S. minuta Bréb., S. splendida (Ehrenb.) Kütz., S. visurgis Hust.

\section{Dinophyceae \\ Peridinium cinctum (O.F. Müll) Ehrenb. \\ Chlorophyta}

Volvocales : Carteria asterochloris H. Ettl, Chlamydomonas aepibiotica $\mathrm{H}$. Ettl, ${ }^{*} C$. mantonii $(\mathrm{H}$. Ettl) H. Ettl, ${ }^{*} C$. petasus H. Ettl, C. spinifera H. Ettl, Chlamydomonas spp., Chlorogonium acutiforme Bourr., Diplostauron angulosum Korshikov, Pedinomonas minor Korshikov, Phacotus lenticularis (Ehrenb.) F. Stein

Chlorococcales : Actinastrum hantzschii Lagerh., Coelastrum astroideum De Not., C. cambricum Arch., Desmatractum delicatissimum Korshikov, Golenkinia radiata Chodat, Kirchneriella lunaris (Kirchn.)
Schmidle, Micractinium pusillum Fresen., Monoraphidium contortum (Thur.) Komárk.-Legn., Pediastrum boryanum (Turpin) Menegh., Oocystella parva (W. et G.S. West) Hindák, Polyedriopsis spinulosa (Schmidle) Schmidle, Pseudodidymocystis inconspicua (Korshikov) Hindák, P. planctonica (Korshikov) E.H. Hegew. et Deason, Scenedesmus abundans (Kirchn.) Chodat, $S$. acuminatus (Lagerh.) Chodat, S. communis E.H. Hegew., ${ }^{*} S$. protuberans Fritsch, Tetraedron caudatum (Corda) Hansg., Tetrastrum staurogeniaeforme (Schröd.) Lemmerm.

\section{Ulotrichales : Elakatothrix acuta Pascher}

\section{Conjugatophyceae}

Cosmarium sp., Staurastrum chaetoceros (Schröd.) G.M. Smith, Staurastrum sp.

\section{Euglenophyceae}

Euglena agilis H.J. Carter, E. anabaena Mainx, Trachelomonas stokesii Drezep.

\subsection{Neuston in the garden pot}

The neuston film on the water surface in the garden pot situated in a small park in the main square of Bratislava, the Slovak National Uprising Square, was intensively dark green in colour, hence apparent, but in limited quantity, however. In this neuston, the dominant species were $E$. agilis and $E$. viridis. In contrast to the neuston of the forest fishpond, the envelopes of cysts of both species were not so intensively brownish but distinctly thick. The garden pot was mostly shadowed by the neighbouring trees and exposed to direct sunlight only for some time.

\section{Acknowledgments}

The authors thanks are due to Dr. E. Hegewald, Jülich Research Centre, Jülich, Germany, for his help with SEM microphotographs, Mrs C. Waligorska-Acheson for polishing the English version of this work.

\section{References}

Bednarz T. 1974. - A unique neustonic bloom of Euglena granulata var. polymorpha. Fragm. Florist. Geobot., 20 : 553-556.

Buetow D.E. 1968. - Morphology and ultrastructure of Euglena. In Buetow D.E. (Ed.) The biology of Euglena, V. I, Academic Press, New York and London : 110-181.

Coghburn J.N. \& J.A. Schiff. 1984. - Purification and properties of the mucus of $E$. gracilis (Euglenophyceae). J. Phycology, 20 : 533-544.

Gojdics M. 1953. - The genus Euglena. Madison, The University of Wisconsin Press : 268 p.

Hindák F. 1981. - On some algal species living in the mucilage of the colonial blue-green alga Microcystis aeruginosa. Biológia, Bratislava, 36 : 809-816.

Hindák F. 1982. - The forming of Trachelomonas-like resting cysts in the genus Euglena or a new representative of Euglenophyceae? Biológia, Bratislava, 37 : 873-879. 
Hindák F. 1986. - Trachelomonas-like resting cysts in Euglena pisciformis Klebs. Biológia, Bratislava, 41 : 913-922.

Hindák F. \& Hindáková A. 1998. - Sinice/cyanobaktérie a riasy [Cyanophyta/Cyanobakteria and algae], p. 11-100. In : Marhold K. \& Hindák F. (Eds), Zoznam nižšich a vyššich rastlin Slovens$\mathrm{ka}$ [Checklist of non-vascular and vascular plants of Slovakia]. Veda, VSAV, Bratislava : 688 p.

Huber-Pestalozzi G. 1955. - Das Phytoplankton des Süsswassers, 4. Teil Euglenophyceae. Die Binnengewässer, 16 (4) : 1-606.

Korshikov O.A. 1953. — Pidklas Protokokovi (Protococcineae). Vakuolni (Vacuolales) ta Protokokovi (Protococcales). Viznachnik Prisnovodnykh vodorostei Ukrainskoi RSR, 5 : 1-440.
Pascher A. 1942. - Über einige mit Schwimmschirmchen versehene Organismen der Wasseroberfläche. Beih. Bot. Centralbl., 61 (A) : 462-487.

Pringsheim E. G. 1956. - Contribution towards a monograph of the genus Euglena. Nova Acta Leop., B. 18, $125: 168$ p.

Skuja H. 1948. - Taxonomie des Phytoplanktons einiger Seen in Uppland, Schweden. Symb. Bot. Upsal., 9 : 1-399.

Starmach K. 1983. - Euglenophyta - eugleniny. Flora słodkowodna Polski, 3 : 1-595. 